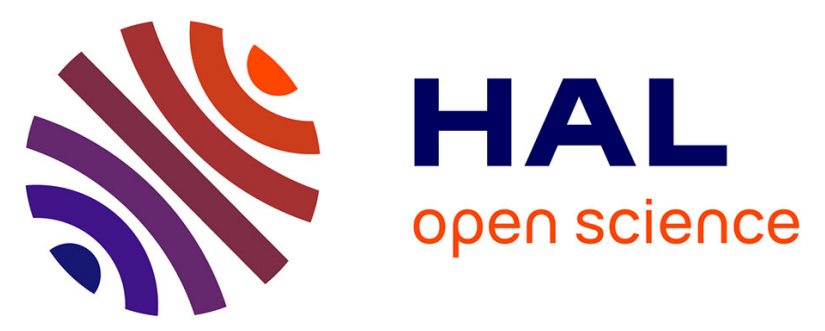

\title{
Why are conspiracy theories more successful in some countries than in others? An exploratory study on Internet users from 22 Western and non-Western countries
}

\author{
Laurent Cordonier, Florian Cafiero, Gérald Bronner
}

\section{To cite this version:}

Laurent Cordonier, Florian Cafiero, Gérald Bronner. Why are conspiracy theories more successful in some countries than in others? An exploratory study on Internet users from 22 Western and nonWestern countries. Social Science Information, 2021, 10.1177/05390184211018961 . hal-03264549

\author{
HAL Id: hal-03264549 \\ https://hal.science/hal-03264549
}

Submitted on 18 Jun 2021

HAL is a multi-disciplinary open access archive for the deposit and dissemination of scientific research documents, whether they are published or not. The documents may come from teaching and research institutions in France or abroad, or from public or private research centers.
L'archive ouverte pluridisciplinaire HAL, est destinée au dépôt et à la diffusion de documents scientifiques de niveau recherche, publiés ou non, émanant des établissements d'enseignement et de recherche français ou étrangers, des laboratoires publics ou privés. 
To cite this paper: Cordonier, L., Cafiero, F., \& Bronner, G. (2021). Why are conspiracy theories more successful in some countries than in others? An exploratory study on Internet users from 22 Western and non-Western countries. Social Science Information, OnlineFirst, https://doi.org/10.1177/05390184211018961

\title{
Why are conspiracy theories more successful in some countries than in others? An exploratory study on Internet users from 22 Western and non- Western countries
}

\author{
Laurent Cordonier* \\ Paris-Diderot University, LIED (CNRS, UMR 8236); Fondation Descartes, France \\ Florian Cafiero \\ Paris Sorbonne University, GEMASS (CNRS, UMR 8598), France
}

\section{Gérald Bronner}

Paris-Diderot University, LIED (CNRS, UMR 8236), France

\author{
*Corresponding author \\ Laurent Cordonier \\ Université Paris Diderot \\ 54 Rue Alice Domon et Léonie Duquet, 75013 Paris, France \\ laurent.cordonier@gmail.com
}

\begin{abstract}
This exploratory study aims at identifying macro-social factors associated with the international variance of belief in conspiracy theories. We computed a Conspiracy Index for 22 Western and nonWestern countries based on the results of an online survey on conspiratorial beliefs. Stepwise regression analyses show that more than $70 \%$ of the international variance of this Conspiracy Index is explained by the following three national variables: the level of democracy, the unemployment rate, and the perceived level of public sector corruption. Conspiracy theories thus appear to be more commonly endorsed in countries where people cannot take an active part in the political life of their country (low level of democracy), where they may feel socially threatened (high unemployment rate), and where institutions and authorities are perceived as untrustworthy (high perception of public sector corruption).
\end{abstract}

\section{Keywords}

conspiracy theories, distrust of authorities, international comparison, public sector corruption, social threat

\footnotetext{
Résumé

Cette étude exploratoire entend identifier les facteurs macro-sociaux associés à la variance internationale du niveau de croyance dans les théories du complot. Nous avons construit un indice de complotisme pour 22 pays occidentaux et non-occidentaux à partir des résultats d'un sondage en ligne sur les croyances conspirationnistes. Une analyse de régression pas à pas montre que plus de $70 \%$ de la
} 
variance internationale de cet indice peut être expliquée par les trois variables nationales suivantes : le niveau de démocratie, le taux de chômage et le niveau perçu de corruption du secteur public. Les théories du complot semblent ainsi être plus communément admises dans les pays où la population n'est pas en mesure de prendre activement part à la vie politique (faible niveau de démocratie), où elle se sent socialement menacée (taux de chômage élevé) et dans lesquels les institutions et les autorités sont perçues comme n'étant pas dignes de confiance (secteur public perçu comme corrompu).

\section{Mots-clés}

comparaison internationale, corruption du secteur public, défiance envers les autorités, menace sociale, théories du complot

\section{Introduction}

Conspiracy theories are narratives claiming that malevolent groups secretly manipulate the functioning of societies, and that authorities, the media, and/or scientists lie to the public about the real causes of significant events. Psychologists Robert Brotherton and Silan Eser (2015: 1) note that conspiracy theories have the following main characteristics: ' ... the label 'conspiracy theory' $[. .$.$] typically refers to$ claims of conspiracy which are less plausible than alternative explanations, contradict the general consensus among epistemic authorities, are predicated on weak evidence, postulate unusually sinister and competent conspirators, and are ultimately unfalsifiable.'

Several national and international surveys have shown that a significant proportion of the population in Western countries believes in various conspiracy theories (see, for example, YouGov, 2018). One reason for concern about the success of these theories is that there is a link between the endorsement of some of them and an inclination towards political and/or religious violence (Bronner, 2013, 2015). This link can be illustrated by recent tragedies, such as the 2019 attacks on the Muslim community in Christchurch, New Zealand, committed by a terrorist who referred to the 'Great Replacement' conspiracy theory to justify his actions, or the current wave of violence targeting Jews in the New York area, which is motivated by anti-Semitic conspiracy theories (Levenson, 2020). Other conspiratorial beliefs can have adverse public health consequences. For example, it has been shown that parents who believe in conspiracy theories according to which the government and pharmaceutical companies cover up the alleged dangers of vaccines are less willing than other parents to vaccinate their children (Shapiro, Holding, Perez, et al., 2016).

\section{Belief in conspiracy theories}

There has been a considerable amount of research focusing on the psychological factors associated with belief in conspiracy theories. Cognitive and social psychologists have shown, for example, that conspiratorial beliefs are related to a variety of cognitive biases (e.g., Brotherton and French, 2014; Wagner-Egger, Delouvée, Gauvrit, et al., 2018), to intuitive (v. analytical) thinking style (e.g., Swami, Voracek, Stieger, et al., 2014), and to paranormal beliefs (e.g., Bruder, Haffke, Neave, et al., 2013). It has also been argued that conspiracy beliefs form part of a 'monological belief system' in which a conspiratorial idea serves as evidence for other conspiracist ideation (Goertzel, 1994). This hypothesis is corroborated by numerous studies showing that the strongest predictor of belief in particular conspiracy theories is often belief in other conspiracy theories and that conspiracy beliefs tend to correlate strongly with each other (e.g., Brotherton, French and Pickering, 2013; Goertzel, 1994; Swami et al., 2011).

In comparison, less research has been done on the social conditions that underlie conspiratorial beliefs (DiGrazia, 2017). Some studies indicate that conspiracy theories are particularly likely to attract individuals belonging to disadvantaged social groups, as well as those who feel socially threatened - for example, people worried about losing their job (DiGrazia, 2017; Goertzel, 1994; Mazzocchetti, 2012). 
These individuals can probably find in conspiracy theories an alternative worldview that makes sense of their situation and designates an unequivocal cause for the social injustices they believe (rightly or wrongly) to be victims of (Abalakina-Paap, Stephan, Craig, et al., 1999; Hofstadter, 1996; Mazzocchetti, 2012; Sullivan, Landau, and Rothschild, 2010). More broadly, political scientists Joseph E. Uscinski and Joseph M. Parent (2014) argue that 'conspiracy theories are for losers': these theories appeal to people who perceive themselves to be on the margins of society (the 'losers') because they would allow them to regain a sense of power.

It has also been shown that distrust of authorities, institutions, and the media is a factor strongly associated with conspiratorial beliefs (Abalakina-Paap et al., 1999; Barkun, 2003; Cordonier, 2021). Such mistrust could be both a consequence and a cause of belief in conspiracy theories. Indeed, in many conspiracy theories, the authorities and the media are presented as protagonists of the conspiracy. This could lead individuals convinced by these theories to distrust their government and the journalists. At the same time, individuals who distrust the authorities and the media will logically tend to reject their 'official explanations' of significant events. These individuals are thus more likely than others to be attracted to conspiratorial 'alternative explanations' of these events.

The propensity to endorse conspiratorial beliefs is also linked to individuals' political orientation. Indeed, as several studies have shown, people at the extreme ends of the political spectrum are more likely than others to believe in conspiracy theories (e.g., Van Prooijen, Krouwel, and Pollet, 2015). Finally, some studies have found that conspiratorial beliefs are negatively related to educational level (Douglas, Sutton, Callan, et al., 2016; Mancosu, Vassallo, and Vezzoni, 2017; Van Prooijen, 2017). However, this relationship is not systematically found in correlational studies (see for e.g., Goertzel, 1994).

Except for these few factors - sense of social threat, mistrust of authorities, institutions, and the media, political extremism and, probably, low educational attainment - little is known about the social variables that may explain, at the national level, why some groups of individuals are more receptive to conspiracy theories than others. Even less research has been done on the macro-social factors associated with the international variance of belief in conspiracy theories. To our knowledge, only one study has attempted to identify these factors on the basis of an international survey on conspiratorial beliefs (Drochon, 2018). This survey, conducted in 2016, covered six European countries (Great Britain, Germany, Italy, Poland, Portugal, and Sweden). Without detailing the methodology followed, the author of the study comes to the following conclusions:

Poorer and less democratic countries, as measured by indices such as GDP, the Democracy Index, Transparency International, and the Gini coefficient [...] return higher levels of conspiracy thinking than those that do better. [...] So countries in which inequality is higher and democracy is considered not to be functioning as well as it should - that is, where citizens feel excluded politically and economically - will exhibit higher levels of conspiracy thinking.

(Drochon, 2018: 337-338)

In countries with little or no democracy, citizens cannot take an active part in the political life of their country, nor can they express themselves freely or access trustable information from independent media sources. Such a situation could increase the feeling of political powerlessness among the population, which could in turn lead to high levels of conspiratorial thinking. Studies have indeed shown that people who feel powerless are particularly receptive to conspiracy theories (Abalakina-Paap et al., 1999; Van Prooijen and Acker, 2015).

Other studies point out that the popularity of certain conspiracy theories varies from country to country depending on cultural and geopolitical factors (e.g., Mashuri, Zaduqisti, Sukmawati, et al., 2016; Swami, 2012). For example, a case study in Indonesia shows that '[...] Muslims believe in anti-West conspiracy theories because they perceive the West as posing a symbolic and realistic threat to Muslims' group entity' (Mashuri et al., 2016: 2). In addition, the governments of some countries themselves 
encourage the dissemination of conspiracy theories for propaganda purposes, as it is for example the case in Russia (e.g., Yablokov, 2015).

\section{The present study}

The aim of this study is to identify macro-social factors associated with the international variance of belief in conspiracy theories. To do so, we first computed a Conspiracy Index for 22 Western and nonWestern countries based on the results of an online survey on conspiratorial beliefs conducted in 2019 . Second, we conducted correlation and stepwise regression analyses to assess the relationships between the Conspiracy Index of the 22 countries and a set of national variables. The following macro-social variables were selected on the basis of the existing literature:

1) Level of democracy: It has been suggested that the level of democracy is negatively related to the level of conspiracy belief (Drochon, 2018). To test this hypothesis, we took into account the following national variables in our analyses: the Democracy Index, the level of freedom of the press, and the level of freedom of discussion. The levels of freedom of the press and of discussion are relevant as proxy for a country's level of democracy.

2) Distrust of institutions and authorities: Studies have shown that distrust of institutions and authorities is positively related to conspiratorial beliefs (Abalakina-Paap et al., 1999; Barkun, 2003; Cordonier, 2021). To account for this factor, we included the following national variables in our analyses: the perceived level of public sector corruption and the perceived level of politicians' ethics. The rationale is that if people perceive their institutions as corrupt and/or their politicians as behaving unethically then, by definition, they view them as untrustworthy.

3) Social threat: Populations that feel socially threatened tend to be more conspiratorial than others (DiGrazia, 2017; Goertzel, 1994). To account for this factor, the following national variables were included in our analyses: the unemployment rate, the intentional homicide rate, and the level of life satisfaction. These indicators of social threat were chosen because they are computed according to the same methodology for all countries and therefore allow for a valid international comparison.

4) Income, inequality, and education: Low levels of economic inequality and high levels of income and education appear to protect against conspiratorial beliefs (Douglas et al., 2016; Drochon, 2018; Mancosu et al., 2017; Van Prooijen, 2017). To account for these factors, we incorporated the following national variables into our analyses: the Gini Index, which measures income inequality within a country, and the Human Development Index, which is a summary measure of average standard of living, educational level, and life expectancy at birth in a country.

\section{Material and methods}

\section{Conspiracy Index}

We computed a Conspiracy Index based on an online survey of the YouGov Institute conducted in 22 countries from February 28 to March 26, 2019. This survey is part of the YouGov-Cambridge Globalism Project. ${ }^{1}$ It should be noted that we took no part in the design or execution of this survey and that we used the data made publicly available by YouGov on its website. ${ }^{2}$

\footnotetext{
1 https://yougov.co.uk/topics/international/articles-reports/2019/05/01/about-yougov-cambridge-globalismproject

2 https://d25d2506sfb94s.cloudfront.net/cumulus_uploads/document/2c6lta5kbu/YouGov\%20Cambridge\%20Gl obalism $\% 20$ Project $\% 20-\% 20$ Conspiracy $\% 20$ Theories.pdf
} 
In the survey, respondents, all aged 18 and over, were asked to evaluate 8 conspiratorial statements by answering the following question: 'Which of the following statements, if any, would you say are true? (Please select all that apply).' Participants could also select 'None of these' or 'Prefer not to say'. The 8 items tested were the following:

- The US Government knowingly helped to make the 9/11 terrorist attacks happen in America on 11 September 2001 (item called 'September 11 conspiracy' thereafter).

- The truth about the harmful effects of vaccines is being deliberately hidden from the public (item called 'Vaccines conspiracy' thereafter).

- Regardless of who is officially in charge of governments and other organizations, there is a single group of people who secretly control events and rule the world together (item called 'Secret group conspiracy' thereafter).

- The idea of man-made global warming is a hoax that was invented to deceive people (item called 'Global warming conspiracy' thereafter).

- Humans have made contact with aliens and this fact has been deliberately hidden from the public (item called 'Hidden Aliens conspiracy' thereafter).

- The AIDS virus was created and spread around the world on purpose by a secret group or organization (item called 'AIDS conspiracy' thereafter).

- The official account of the Nazi Holocaust is a lie and the number of Jews killed by the Nazis during World War II has been exaggerated on purpose (item called 'Holocaust conspiracy' thereafter).

- (Members of Donald Trump's election team knowingly worked with the Russian Government to help him win the 2016 US Presidential Election.) ${ }^{3}$

Data from this survey are available for the following 22 countries: Australia $(\mathrm{N}$ of respondents $=$ 1006), Brazil $(\mathrm{N}=1006)$, Canada $(\mathrm{N}=1006)$, Denmark $(\mathrm{N}=1010)$, Egypt $(\mathrm{N}=1537)$, France $(\mathrm{N}=$ $1021)$, Germany $(\mathrm{N}=1479)$, India $(\mathrm{N}=1035)$, Indonesia $(\mathrm{N}=1001)$, Italy $(\mathrm{N}=1005)$, Japan $(\mathrm{N}=$ 1143), Mexico ( $\mathrm{N}=1009)$, Nigeria $(\mathrm{N}=644)$, Poland $(\mathrm{N}=1019)$, Saudi Arabia $(\mathrm{N}=828)$, South Africa $(\mathrm{N}=1002)$, Spain $(\mathrm{N}=1014)$, Sweden $(\mathrm{N}=1011)$, Thailand $(\mathrm{N}=1043)$, Turkey $(\mathrm{N}=506)$, United Kingdom (UK) $(\mathrm{N}=1949)$, United States (US) $(\mathrm{N}=2012)$.

The Conspiracy Index was computed as follows. First, we discarded the item on Russian interference in the 2016 US elections (last item listed above). Indeed, this item does not correspond to the definition of a conspiracy theory. It does not, for example, fit into the criteria of a conspiracy theory retained by Brotherton \& Eser (2015), because there is no consensus among the epistemic authorities on the exact extent and nature of Russian interference in the 2016 US elections. Due to this lack of consensus among the epistemic authorities, it is possible that reliable media sources published contradictory information on this topic. Therefore, we discarded this last item to avoid introducing unnecessary noise in the construction of the Conspiracy Index.

Second, we averaged for each country the percentage of positive assessments (i.e., percentage of 'true' answers) received by the 7 remaining conspiratorial statements. These averages correspond to the Conspiracy Index of the 22 countries (see Figure 1 and Table 1). Aggregating various conspiratorial items in this way is justified by the monological nature of conspiracist ideation (Goertzel, 1994) and is a common procedure in conspiracy theory research (see, for example, Brotherton et al., 2013; Bruder et al., 2013; Goertzel, 1994; Lantian, Muller, Nurra, et al., 2016; Swami et al., 2011).

Note that YouGov did not test the Holocaust conspiracy item in Germany. To compensate for this missing data, we computed the mean value of this item among the 21 other countries and attributed it to Germany.

\footnotetext{
${ }^{3}$ This item was not included in our Conspiracy Index.
} 


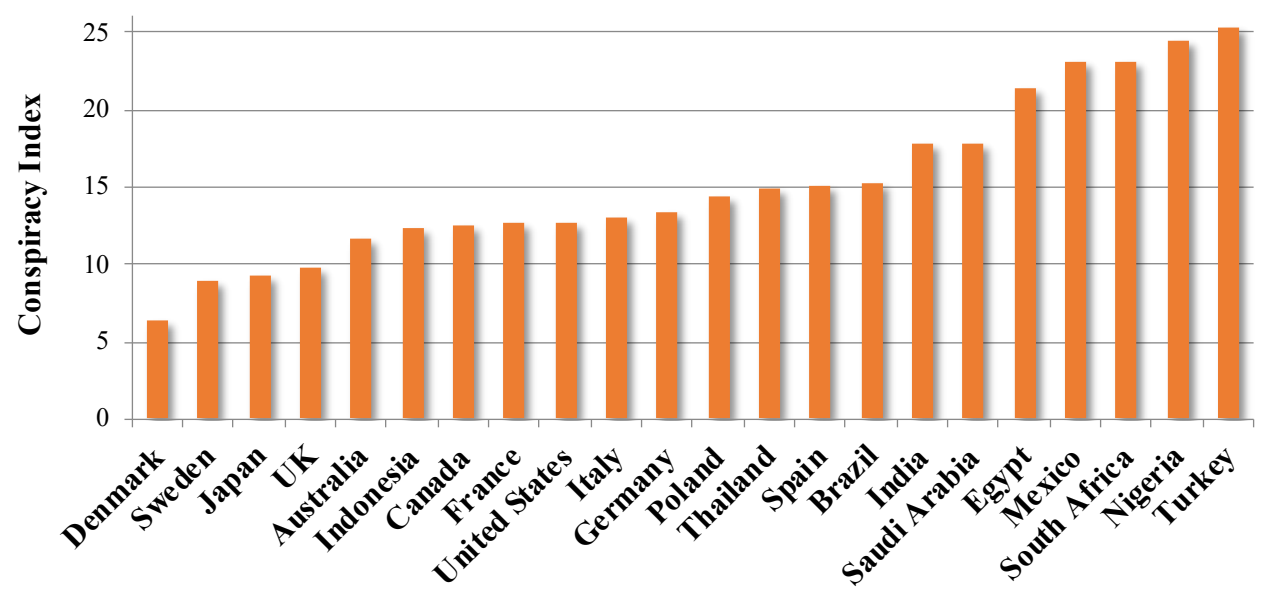

Figure 1. Conspiracy Index of the 22 countries

Table 1. Descriptive statistics of the Conspiracy Index and of its 7 items $(\mathrm{N}=22$ countries)

\begin{tabular}{llllll}
\hline & Min. & Max. & Mean & Median & SD \\
\hline Conspiracy Index & 6.29 & 25.29 & 15.23 & 13.93 & 5.18 \\
- September 11 conspiracy (\% of 'true') & 7 & 36 & 17.55 & 15.50 & 7.25 \\
- Vaccines conspiracy (\% of 'true') & 7 & 32 & 18.27 & 17.00 & 6.53 \\
- Secret group conspiracy (\% of 'true') & 7 & 46 & 25.41 & 25.00 & 9.52 \\
- Global warming conspiracy (\% of 'true') & 4 & 17 & 9.91 & 9.50 & 3.54 \\
- Hidden Aliens conspiracy (\% of 'true') & 7 & 26 & 13.77 & 14.00 & 4.66 \\
- AIDS conspiracy (\% of 'true') & 3 & 30 & 12.64 & 9.50 & 7.97 \\
- Holocaust conspiracy (\% of 'true') & 2 & 25 & 9.05 & 8.00 & 5.69 \\
\hline \hline
\end{tabular}

The 7-item Conspiracy Index computed for the 22 countries has a very good internal consistency (Cronbach alpha test, $\mathrm{N}=22,7$ items, $\alpha=0.89$ ) and its distribution between the 22 countries does not significantly differ from normality (Shapiro-Wilk test, $\mathrm{N}=22, W=0.93, p=0.15$; see Figure 2). Unfortunately, we were unable to conduct these analyses at the individual level within each country, because YouGov did not give us access to detailed data by country. However, prior research has systematically found satisfactory internal consistency at the individual level between various conspiracy items tested in a given country (e.g., Brotherton et al., 2013; Bruder et al., 2013; Goertzel, 1994; Lantian et al., 2016; Swami et al., 2011). 


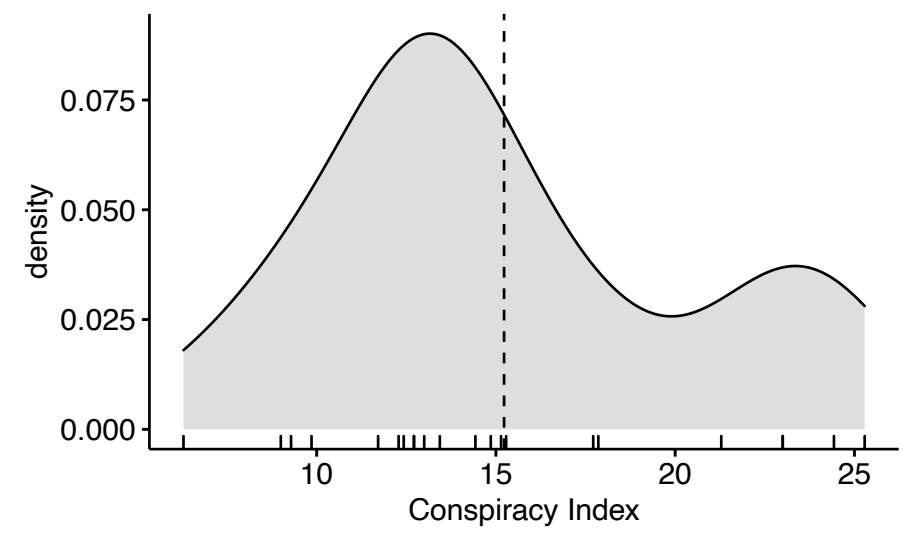

Figure 2. Density plot of the Conspiracy Index $(\mathrm{N}=22)$. The vertical dashed line indicates the mean value of the Conspiracy Index.

It should be noted that the YouGov survey we used to compute the Conspiracy Index was conducted online, which probably limits its demographic representativeness in countries where the Internet is used by only a minority of the population. We therefore take the Conspiracy Index as an indicator of the level of conspiratorial beliefs among the Internet users of the 22 countries rather than as an indicator of the prevalence of conspiratorial beliefs among the overall population of these countries.

While the demographic representativeness of the YouGov survey is limited by the fact that it has been conducted online, this also represents an advantage. By definition, this survey measured the conspiratorial beliefs of individuals who all have access to the conspiracy theories circulating on the web. As the Internet is an important vector of conspiracy theories (e.g., Bronner, 2013), it is not unjustified to compare the success of an identical set of conspiracy theories among these individuals, even though they live in societies that differ significantly from each other in many ways.

In addition to its lack of demographic representativeness, another potential limitation of the YouGov survey lies in the fact that, at the national level, the success of some of the conspiracy theories tested might depend more on cultural and geopolitical factors than on the actual level of conspiratorial thinking among the population. For example, a strong anti-American sentiment in a given country could increase respondents' tendency to endorse an item such as the September 11 conspiracy, not necessarily because they believe in this specific theory but to express their hatred for the US.

In our study, the level of the Conspiracy Index is significantly lower in the 11 Western countries covered by the YouGov survey (Australia, Canada, Denmark, France, Germany, Italy, Poland, Spain, Sweden, UK, US; mean Conspiracy Index $=11.88$ ) than in the 11 non-Western countries (mean Conspiracy Index $=18.57$; bilateral t-test: $t(20)=3.79, p=0.001$; see Figure 3$)$. This could suggest that our index is culturally biased. 


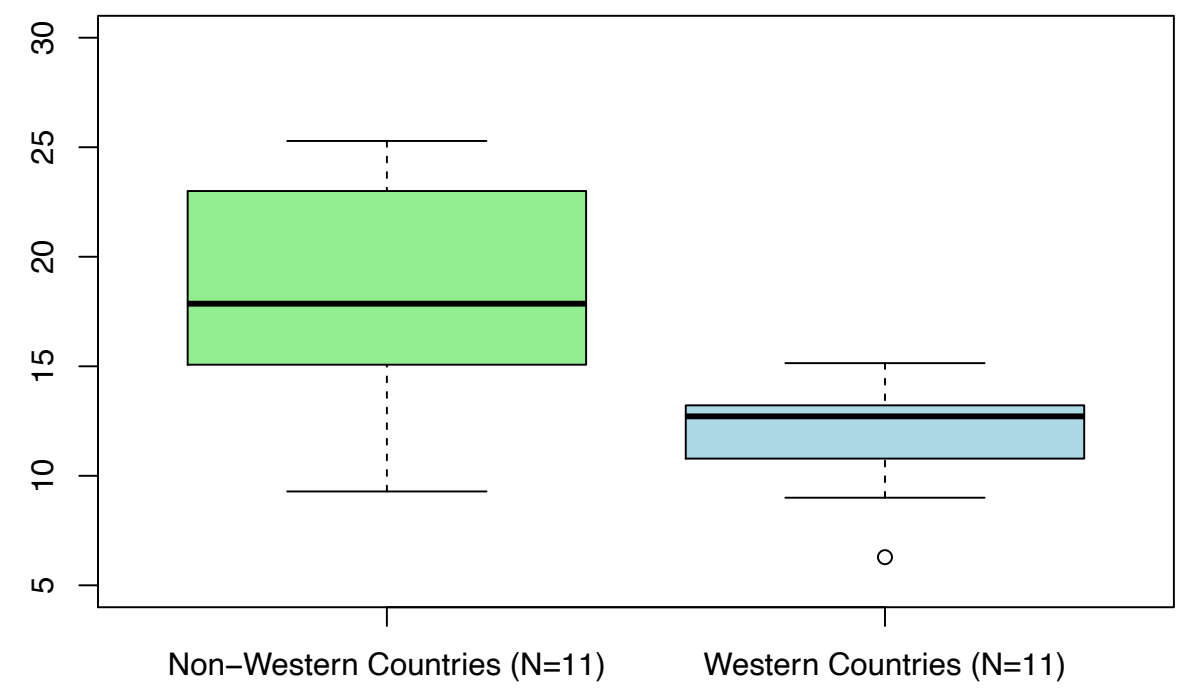

Figure 3. Level of the Conspiracy Index in the non-Western and Western countries

The possibility of such a bias is a common concern in studies using results of international surveys on conspiratorial beliefs. In an attempt to overcome it, psychologists have developed standardized conspiracy scales using generic items - that is, items that avoid mentioning any specific alleged conspiracy and that do not name any specific groups potentially responsible for a conspiracy (Brotherton et al., 2013; Bruder et al., 2013).

In the YouGov survey we used to compute the Conspiracy Index, only one item is generic in this sense: the Secret group conspiracy ('Regardless of who is officially in charge of governments and other organizations, there is a single group of people who secretly control events and rule the world together'). This item is close to one of the 5 generic, cross-culturally validated items of the Conspiracy Mentality Questionnaire by Bruder and colleagues (2013): 'I think that there are secret organizations that greatly influence political decisions'. It is also similar to the 3 items termed 'malevolent global conspiracies' in the Generic Conspiracist Beliefs Scale by Brotherton and colleagues (2013) (e.g., 'A small, secret group of people is responsible for making all major world decisions, such as going to war').

As the Secret group conspiracy is a generic item, responses to this item are unlikely to be biased by cultural or geopolitical variables (Bruder et al., 2013). In order to control whether or not the Conspiracy Index as a whole is affected by cultural or geopolitical factors, we computed its value for each country with 6 items only, excluding the generic Secret group conspiracy one. Next, we compared the level of this 6-item Conspiracy Index with that of the Secret group conspiracy item among the 22 countries. A correlation analysis shows that the 6-item Conspiracy Index and the Secret group conspiracy item are highly correlated $(R=0.80, p<0.001 ; \mathrm{N}=22$; see Figure 4$)$. This clearly suggests that the Conspiracy Index itself is not fundamentally biased by cultural or geopolitical variables. 


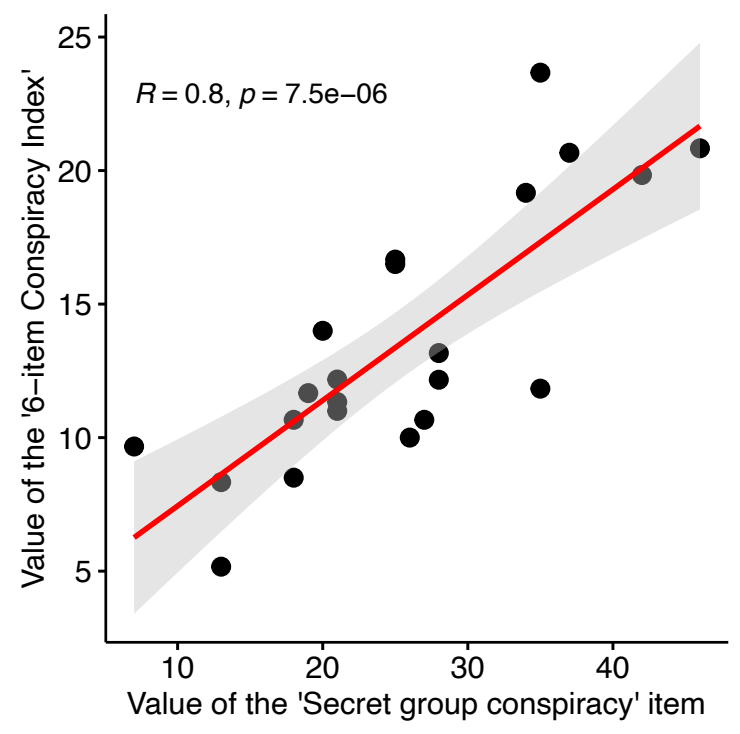

Figure 4. Pearson's correlation between the 6-item Conspiracy Index and the Secret group conspiracy item. Each dot represents a country $(\mathrm{N}=22)$. Grey surface: confidence interval $(95 \%)$.

Moreover, if the responses to the YouGov survey were influenced to a large extent by geopolitical cleavages, items reflecting those cleavages should be those for which the rate of positive evaluations varies the most between the countries. An examination of the evaluations received by each item tested in the 22 countries shows that this is not the case. Indeed, it is the generic Secret group conspiracy item that shows the greatest variability between the 22 countries ( $\mathrm{SD}=9.52$; see Table 1). The September 11 conspiracy item - potentially the weakest item in the YouGov survey, since it is the only one to explicitly mention a national actor - is only in third place out of seven according to this criterion $(\mathrm{SD}=7.25$; see Table 1).

Finally, as mentioned above, the level of the Conspiracy Index is lower in Western than in nonWestern countries. But this difference is not due to a stronger endorsement of some items in particular in the group of non-Western countries, which could have indicated that the Conspiracy Index is culturally biased. On the contrary, there is a quasi-linear relationship between the two groups of countries in the endorsement of each of the 7 items composing the Conspiracy Index (see Figure 5).

Overall, the computed Conspiracy Index has a very good internal consistency and is unlikely to be strongly biased by cultural variables or geopolitical cleavages. This index thus allows a credible comparison of the level of conspiratorial beliefs between Internet users of the 22 countries included in this study. 


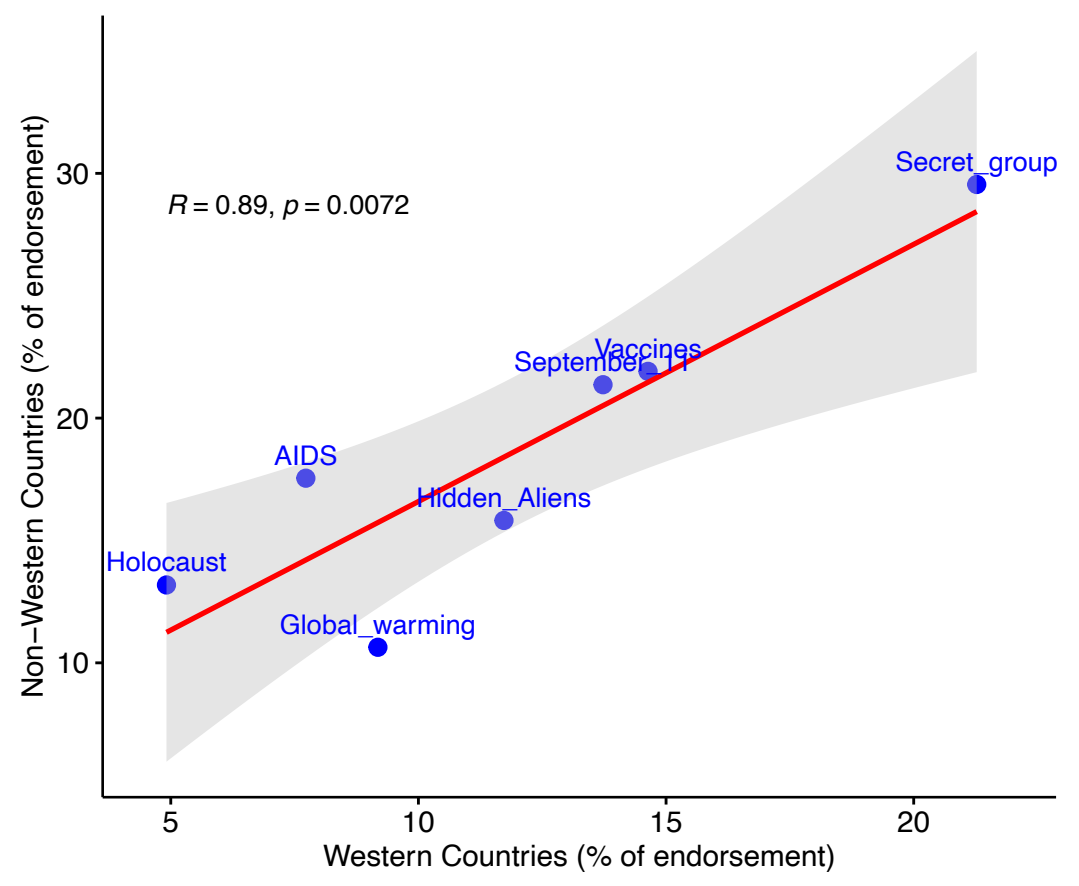

Figure 5. Comparison of the level of endorsement of the 7 items composing the Conspiracy Index between the Western and non-Western countries (Pearson's correlation: $\mathrm{R}=0.89, \mathrm{p}<0.01 ; \mathrm{N}=7$ ). Grey surface: confidence interval (95\%).

\section{Independent variables}

As mentioned in the introduction, we hypothesized that the following variables may contribute to explain the international variance of the Conspiracy Index. The descriptive statistics of the independent variables of the 22 countries taken together are exposed in Table 2.

\section{Freedom of the press (reversed World Press Freedom Index)}

To assess the level of Freedom of the press in each of the 22 countries of this study, we used the 2019 World Press Freedom Index (WPFI). The WPFI is an index published annually by Reporters Without Borders (RSF). It is computed as follows: 'The degree of freedom available to journalists in 180 countries is determined by pooling the responses of experts to a questionnaire devised by RSF. This qualitative analysis is combined with quantitative data on abuses and acts of violence against journalists during the period evaluated. The criteria evaluated in the questionnaire are pluralism, media independence, media environment and self-censorship, legislative framework, transparency, and the quality of the infrastructure that supports the production of news and information. ${ }^{4}$

Note that the higher the WPFI value, the less freedom of the press. In our study, we reversed the polarity of the index using the following transformation for each country's WPFI: 'Reversed WPFI' = (100 - WPFI). Thus, the higher the value of the 'Reversed WPFI' (called Freedom of the press thereafter), the greater the freedom of the press. ${ }^{5}$

Freedom of discussion (mean of 'Freedom of discussion for women' and 'Freedom of discussion for men')

\footnotetext{
${ }^{4}$ https://rsf.org/en/detailed-methodology

${ }^{5}$ Source: Reporters Without Borders; https://rsf.org/en/ranking. Data year: 2019.
} 
To assess the level of Freedom of discussion in each of the 22 countries of this study, we used the 2019 'Freedom of discussion for women' and 'Freedom of discussion for men' indicators made available by the V-Dem Institute. The description of these indicators is the same for women and men: 'This indicator specifies the extent to which women [or men] are able to engage in private discussions, particularly on political issues, in private homes and public spaces (restaurants, public transportation, sports events, work, etc.) without fear of harassment by other members of the polity or the public authorities. We are interested in restrictions by the government and its agents but also cultural restrictions or customary laws that are enforced by other members of the polity, sometimes in informal ways' (Coppedge, Gerring, Knutsen, et al., 2019: 165). The range of values for these indicators goes from $0=$ freedom of discussion not respected to $4=$ freedom of discussion fully respected .

In our study, we averaged for each country the 'Freedom of discussion for women' and 'Freedom of discussion for men' indicators (in the 22 countries of this study, these two indicators are very highly intercorrelated: $\mathrm{R}=0.97 ; \mathrm{p}<0.001 ; \mathrm{N}=22$ ). These averages correspond to the Freedom of discussion values of the 22 countries. ${ }^{6}$

\section{Democracy Index}

The Democracy Index is an index compiled by the Economist Intelligence Unit: 'The Democracy Index is based on five categories: electoral process and pluralism; the functioning of government; political participation; political culture; and civil liberties' (Economist Intelligence Unit, 2019: 3). The higher a country's score, the more democratic is this country.

\section{Corruption perception (reversed Corruption Perception Index)}

To assess the level of Corruption perception in each of the 22 countries of this study, we used the 2019 Corruption Perception Index (CPI). The CPI is an index published annually by Transparency International indicating populations' 'perceived levels of public sector corruption, as determined by expert assessments and opinion surveys'. Corruption is defined as 'the misuse of public power for private benefit'. $^{7}$

Note that the higher the CPI value, the lower the perception of corruption. In our study, we reversed the polarity of the index using the following transformation for each country's CPI: 'Reversed CPI' = $(100-\mathrm{CPI})$. Thus, the higher the value of the 'reversed CPI' (called Corruption perception thereafter), the stronger the perception of corruption. ${ }^{8}$

\section{Politicians' ethics perception}

To assess the public perception of politicians' ethics (called Politicians' ethics perception thereafter), we used the following item from the Global Competitiveness Index established by the World Economic Forum (index component 1.04): 'In your country, how would you rate the ethical standards of politicians?' Answers range from 1 = 'extremely low' to 7 = 'extremely high' (World Economic Forum, 2017).

\section{Unemployment}

The unemployment rate for each of the 22 countries of this study is that indicated by the World Bank. It is expressed in \% of total labor force (modeled ILO estimate). ${ }^{9}$

\footnotetext{
6 Source: V-Dem - Varieties of Democracy, V-Dem Dataset Version 9; https://www.vdem.net/en/data/archive/previous-data/data-version-9/. Data year: 2018.

${ }^{7} \mathrm{https}: / /$ www.transparency.org/

${ }^{8}$ Source: Transparency International; https://www.transparency.org/cpi2019\#downloads. Data year: 2019.

${ }^{9}$ Source: https://data.worldbank.org/indicator/SL.UEM.TOTL.ZS. Data year: 2019.
} 


\section{Intentional homicides}

The intentional homicides rate for each of the 22 countries of this study is expressed as the number of homicides per 100000 people. The World Bank's description of this indicator is the following: 'Intentional homicides are estimates of unlawful homicides purposely inflicted as a result of domestic disputes, interpersonal violence, violent conflicts over land resources, intergang violence over turf or control, and predatory violence and killing by armed groups. Intentional homicide does not include all intentional killing; the difference is usually in the organization of the killing. Individuals or small groups usually commit homicide, whereas killing in armed conflict is usually committed by fairly cohesive groups of up to several hundred members and is thus usually excluded. 10

\section{Life satisfaction}

Life satisfaction is a self-reported measure corresponding to the average answer to the Cantril Ladder question in the Gallup World Poll: 'Please imagine a ladder, with steps numbered from 0 at the bottom to 10 at the top. The top of the ladder represents the best possible life for you and the bottom of the ladder represents the worst possible life for you. On which step of the ladder would you say you personally feel you stand at this time? ${ }^{11}$

\section{Gini Index (inequality index)}

The US Central Intelligence Agency (CIA) description of this indicator is the following: 'Gini index measures the degree of inequality in the distribution of family income in a country. The more nearly equal a country's income distribution, the lower its Gini index [...]. The more unequal a country's income distribution, the higher its Gini index [...]. If income were distributed with perfect equality the index would be zero; if income were distributed with perfect inequality, the index would be $100 .{ }^{12}$

\section{Human Development Index}

The United Nations Development Programme's description of this indicator is the following: 'The Human Development Index (HDI) is a summary measure of average achievement in key dimensions of human development: a long and healthy life, being knowledgeable and have a decent standard of living. The HDI is the geometric mean of normalized indices for each of the three dimensions. The health dimension is assessed by life expectancy at birth, the education dimension is measured by mean of years of schooling for adults aged 25 years and more and expected years of schooling for children of school entering age. The standard of living dimension is measured by gross national income per capita. ${ }^{, 13}$

\footnotetext{
${ }^{10}$ Source: The World Bank; https://data.worldbank.org/indicator/VC.IHR.PSRC.P5. Data years are the most recent data available for each country: 2012 for Egypt and Turkey; 2015 for Nigeria; 2016 for India, Italy, and Thailand; 2017 for the 16 remaining countries.

${ }^{11}$ Source: Gallup World Poll; https://ourworldindata.org/happiness-and-life-satisfaction. Data years are the most recent data available for each country: 2017 for Poland; 2018 for the other 21 countries.

12 Source: https://www.cia.gov/the-world-factbook/field/gini-index-coefficient-distribution-of-familyincome/country-comparison. Data years (most recent data available for each country): 2005 for Canada, 2006 for Germany, 2007 for the United States, 2008 for Australia, 2009 for Indonesia, 2010 for Turkey, 2011 for India and Japan, 2012 for Italy, Spain, and the UK, 2013 for Nigeria, Saudi Arabia, South Africa, and Sweden, 2014 for Brazil and Mexico, 2015 for Egypt, Poland, and Thailand, 2016 for Denmark and France.

${ }^{13}$ Source : http://hdr.undp.org/en/content/human-development-index-hdi. Data year: 2018. Source: United Nations Development Programme; http://hdr.undp.org/en/data\#
} 
Table 2. Descriptive statistics of the independent variables $(\mathrm{N}=22$ countries)

\begin{tabular}{llllll}
\hline & Min. & Max. & Mean & Median & SD \\
\hline 1) Level of democracy & & & & & \\
$\quad$ Freedom of the press (reversed WPFI) & 34.12 & 91.69 & 69.08 & 72.71 & 15.23 \\
$\quad$ Freedom of discussion (mean women and men) & -1.55 & 2.79 & 1.36 & 1.56 & 1.34 \\
$\quad$ Democracy Index & 1.93 & 9.39 & 6.99 & 7.38 & 2.02 \\
2) Distrust of institutions and authorities & & & & & \\
$\quad$ Corruption perception (reversed CPI) & 13 & 74 & 43.41 & 44.50 & 19.31 \\
$\quad$ Politicians' ethics perception & 1.32 & 5.24 & 3.51 & 3.68 & 1.37 \\
3) Social threat & & & & & \\
$\quad$ Unemployment (\% of total labor force) & 0.70 & 27.32 & 7.20 & 5.62 & 5.68 \\
Intentional homicides (per 100 000 people) & 0.20 & 35.90 & 6.00 & 1.30 & 10.06 \\
Life satisfaction (self-reported) & 3.82 & 7.65 & 6.18 & 6.43 & 1.03 \\
4) Income, inequality, and education & & & & & \\
$\quad$ Gini Index (inequality index) & 24.90 & 62.50 & 37.70 & 35.55 & 9.08 \\
$\quad$ Human Development Index & 0.53 & 0.94 & 0.83 & 0.88 & 0.11 \\
\hline \hline
\end{tabular}

\section{Results}

The correlogram in Figure 6 shows the relationships (Pearson's correlations) between all the variables presented in the previous section. It can be observed that, among the 22 countries of this study, the Conspiracy Index is positively associated with Corruption perception $(R=0.81, p<0.001 ; \mathrm{N}=22$; see Figure 7.A), Intentional homicides $(R=0.50, p<0.05 ; \mathrm{N}=22)$, and Gini Index $(R=0.63, p<0.01 ; \mathrm{N}$ $=22$ ).

The positive correlation between the Conspiracy Index and Unemployment is only tendentially significant $(R=0.42, p=0.05 ; \mathrm{N}=22)$.

The Conspiracy Index is negatively associated with Freedom of the press $(R=-0.66, p<0.001 ; \mathrm{N}=$ $22)$, Freedom of discussion $(R=-0.55, p<0.01 ; \mathrm{N}=22)$, Democracy Index $(R=-0.73, p<0.001 ; \mathrm{N}=$ 22; see Figure 7.B), Politicians' ethics perception $(R=-0.60, p<0.01 ; \mathrm{N}=22)$, Life satisfaction $(R=$ $0.66, p<0.001 ; \mathrm{N}=22)$, and $H D I(R=-0.72, p<0.001 ; \mathrm{N}=22)$. 


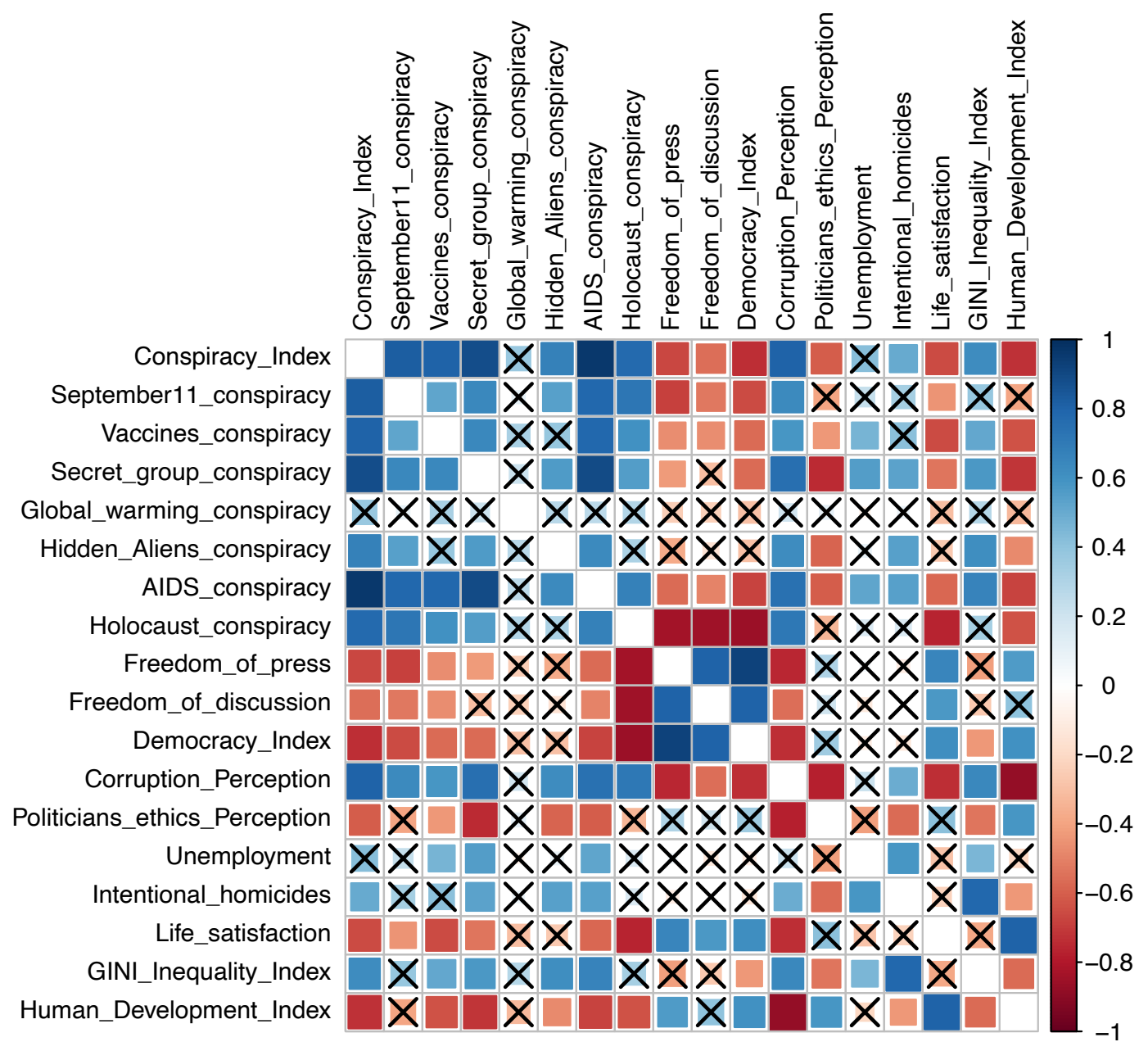

Figure 6. Pearson's correlations between all the variables $(\mathrm{N}=22$ countries). Correlation coefficients $(R)$ not crossed out are statistically significant $(p<0.05)$. 
Human_Development_Index
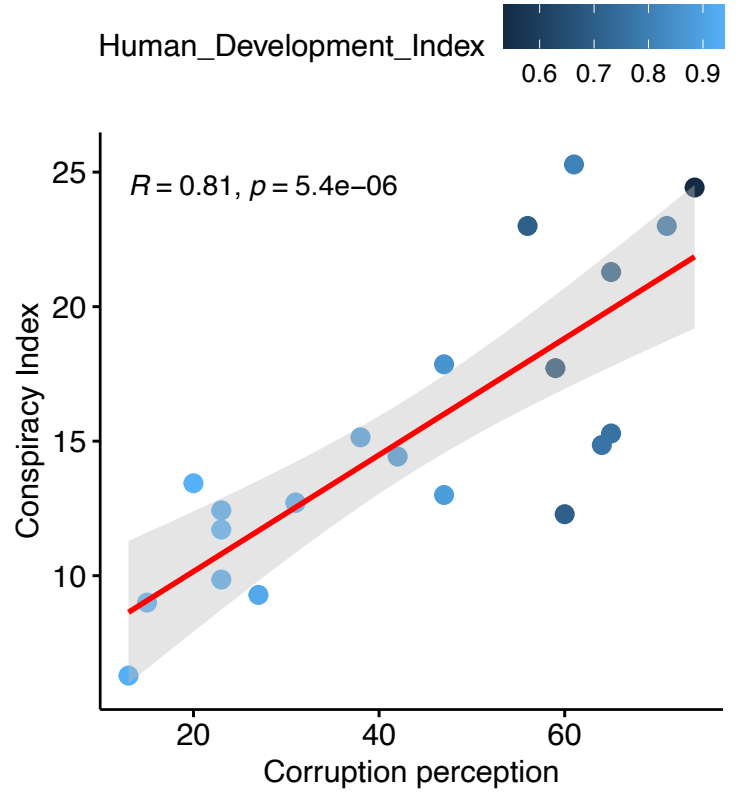

Human_Development_Index

$\begin{array}{llll}0.6 & 0.7 & 0.8 & 0.9\end{array}$

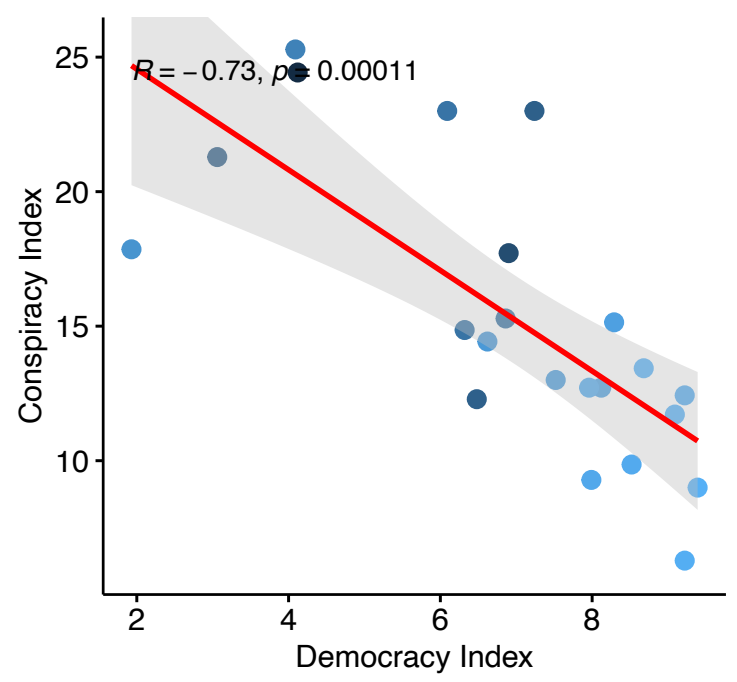

B

Figure 7. Pearson's correlations between the Conspiracy Index and (A) Corruption perception, (B) Democracy Index. Each dot represents a country $(\mathrm{N}=22)$. The color of the dots indicates countries' HDI. Grey surfaces: confidence intervals (95\%).

In order to assess which of the macro-social factors we have taken into account affect the level of conspiratorial beliefs across the 22 countries, we conducted a stepwise multiple linear regression analysis with, as the dependent variable, the Conspiracy Index and, as independent variables, Freedom of the press, Freedom of discussion, Democracy Index, Corruption perception, Politicians' ethics perception, Unemployment, Intentional homicides, Life satisfaction, Gini Index, and HDI. A stepwise regression analysis was used because of the high level of intercorrelation between the independent variables (see Figure 6) and the exploratory nature of this study.

Results show that the best-fitted model includes three independent variables out of ten: Democracy Index, Corruption perception, and Unemployment. This model explains $73 \%$ of the variance of the Conspiracy Index across the 22 countries (Adjusted $R^{2}=0.731, \mathrm{~F}(3,18)=20.03, p<0.001$; see Table 3).

Table 3. Multiple linear regression analysis, best-fitted model. Dependent variable: Conspiracy Index; Independent variables: Democracy Index, Corruption perception, and Unemployment.

\begin{tabular}{lllll}
\hline & Estimate & Std. Error & $t$-value & $p$-value \\
\hline (Intercept) & 13.471 & 4.653 & 2.895 & $0.009^{* *}$ \\
Democracy Index & -0.853 & 0.430 & -1.984 & $0.063^{\circ}$ \\
Corruption perception & 0.135 & 0.046 & 2.940 & $0.009^{* *}$ \\
Unemployment & 0.259 & 0.106 & 2.444 & $0.025^{*}$ \\
\hline
\end{tabular}

Residual standard error: 2.748 on 18 degrees of freedom; Multiple $R^{2}=0.770$; Adjusted $R^{2}=0.731$; Fstatistic: 20.03 on 3 and $18 \mathrm{DF} ; p<0.001$. 
To evaluate whether the result of this regression analysis is driven by a specific conspiracy item or a specific country, we conduced robustness analyses by testing the best-fitted model (dependent variable: Conspiracy Index; independent variables: Democracy Index, Corruption perception, and Unemployment) by omitting, first, one of the 7 items comprised in the Conspiracy Index at the time and, second, one of the 22 countries at the time:

1) Inspection of Table 4 shows that the result of the initial regression analysis is not driven by a specific item: the weakest adjusted $R^{2}$, obtained by omitting the generic Secret group conspiracy item, is still of $0.679, p<0.001$. Table 5 exposes the complete regression analysis with this item removed from the Conspiracy Index.

2) Inspection of Table 6 shows that the result of the initial regression analysis is not driven by a specific country: the weakest adjusted $R^{2}$, obtained by omitting Denmark, is still of $0.699, p<0.001$. Table 7 exposes the complete regression analysis without this country.

Table 4. Robustness analysis: multiple linear regression analyses (best-fitted model) omitting one of the 7 items comprised in the Conspiracy Index at the time

\begin{tabular}{lllll}
\hline Conspiracy Index & Multiple $R^{2}$ & Adjusted $R^{2}$ & F-statistic* $^{*}$ & -value \\
\hline Omitting September 11 conspiracy & 0.772 & 0.734 & 20.32 & $<0.001$ \\
Omitting Vaccines conspiracy & 0.762 & 0.723 & 19.22 & $<0.001$ \\
Omitting Secret group conspiracy & 0.725 & 0.679 & 15.83 & $<0.001$ \\
Omitting Global warming conspiracy & 0.786 & 0.750 & 22.01 & $<0.001$ \\
Omitting Hidden Aliens conspiracy & 0.787 & 0.752 & 22.17 & $<0.001$ \\
Omitting AIDS conspiracy & 0.764 & 0.725 & 19.44 & $<0.001$ \\
Omitting Holocaust conspiracy & 0.730 & 0.685 & 16.25 & $<0.001$ \\
\hline
\end{tabular}

* On 3 and 18 degrees of freedom

Table 5. Multiple linear regression analysis, best-fitted model. Dependent variable: Conspiracy Index without the Secret group conspiracy item

\begin{tabular}{lllll}
\hline & Estimate & $S t d$. Error & $t$-value & $p$-value \\
\hline (Intercept) & 14.101 & 4.607 & 3.061 & $0.007^{* *}$ \\
Democracy Index & -0.936 & 0.426 & -2.199 & $0.041^{*}$ \\
Corruption perception & 0.107 & 0.045 & 2.349 & $0.030^{*}$ \\
Unemployment & 0.186 & 0.105 & 1.774 & $0.093^{\circ}$ \\
\hline
\end{tabular}

Residual standard error: 2.721 on 18 degrees of freedom; Multiple $R^{2}=0.725$; Adjusted $R^{2}=0.679$; Fstatistic: 15.83 on 3 and $18 \mathrm{DF} ; p<0.001$. 
Table 6. Robustness analysis: multiple linear regression analyses (best-fitted model) omitting one of the 22 countries at the time

\begin{tabular}{lllll}
\hline Countries & Multiple $R^{2}$ & Adjusted $R^{2}$ & F-statistic $^{*}$ & $p_{\text {-value }}$ \\
\hline Omitting Australia & 0.769 & 0.728 & 18.84 & $<0.001$ \\
Omitting Brazil & 0.807 & 0.773 & 23.65 & $<0.001$ \\
Omitting Canada & 0.775 & 0.736 & 19.53 & $<0.001$ \\
Omitting Denmark & 0.744 & 0.699 & 16.47 & $<0.001$ \\
Omitting Egypt & 0.757 & 0.714 & 17.67 & $<0.001$ \\
Omitting France & 0.767 & 0.726 & 18.66 & $<0.001$ \\
Omitting Germany & 0.797 & 0.761 & 22.22 & $<0.001$ \\
Omitting India & 0.772 & 0.731 & 19.14 & $<0.001$ \\
Omitting Indonesia & 0.812 & 0.779 & 25.54 & $<0.001$ \\
Omitting Italy & 0.782 & 0.743 & 20.28 & $<0.001$ \\
Omitting Japan & 0.759 & 0.717 & 17.89 & $<0.001$ \\
Omitting Mexico & 0.787 & 0.749 & 20.92 & $<0.001$ \\
Omitting Nigeria & 0.749 & 0.705 & 16.94 & $<0.001$ \\
Omitting Poland & 0.769 & 0.729 & 18.89 & $<0.001$ \\
Omitting Saudi Arabia & 0.781 & 0.743 & 20.22 & $<0.001$ \\
Omitting South Africa & 0.748 & 0.703 & 16.80 & $<0.001$ \\
Omitting Spain & 0.770 & 0.729 & 18.92 & $<0.001$ \\
Omitting Sweden & 0.753 & 0.709 & 17.23 & $<0.001$ \\
Omitting Thailand & 0.778 & 0.739 & 19.90 & $<0.001$ \\
Omitting Turkey & 0.759 & 0.716 & 17.81 & $<0.001$ \\
Omitting UK & 0.757 & 0.715 & 17.69 & $<0.001$ \\
Omitting USA & 0.768 & 0.727 & 18.78 & $<0.001$ \\
\hline * On 3 and 17 degrees of freedom & & & & \\
\hline \hline & & & & \\
\hline
\end{tabular}

Table 7. Multiple linear regression analysis, best-fitted model. Country excluded: Denmark

\begin{tabular}{lllll}
\hline & Estimate & Std. Error & $t$-value & $p$-value \\
\hline (Intercept) & 14.120 & 4.726 & 2.988 & $0.008^{* *}$ \\
Democracy Index & -0.860 & 0.432 & -1.991 & $0.063^{\circ}$ \\
Corruption perception & 0.124 & 0.047 & 2.614 & $0.018^{*}$ \\
Unemployment & 0.257 & 0.106 & 2.416 & $0.027^{*}$ \\
\hline
\end{tabular}


Residual standard error: 2.760 on 17 degrees of freedom; Multiple $R^{2}=0.744$; Adjusted $R^{2}=0.699$; Fstatistic: 16.47 on 3 and $17 \mathrm{DF} ; p<0.001$.

\section{Discussion}

The aim of this exploratory study was to identify macro-social factors associated with the international variance of belief in conspiracy theories. Using the outcomes of a recent online survey on conspiratorial beliefs covering 22 countries, we found that the level of belief in conspiracy theories is higher among Internet users from countries (1) with weak democracies, (2) where politicians are perceived as behaving unethically and the public sector is perceived as corrupt, (3) where the level of social threat is high, and (4) where income and education levels are low, while the level of economic inequality is high.

Regression analyses suggest that it is not the levels of wealth, education, and economic inequality that directly modulate the success of conspiracy theories among the 22 countries of this study. Indeed, we found that more than $70 \%$ of the international variance in conspiratorial beliefs among these countries is explained by the following three national variables: the level of democracy, the unemployment rate, and the perceived level of public sector corruption.

Since the present study is correlational in nature, it does not allow to conclude with certainty that these macro-social factors play a causal role in the endorsement of conspiracy theories at the individual level. However, as indicated in the introductory section of this paper, previous research has shown that individuals who feel powerless, socially threatened, and who distrust the authorities and institutions are more likely than others to endorse conspiracy theories. Therefore, a country with a low level of democracy, a high unemployment rate, and where the public sector is perceived as highly corrupt offers fertile ground for conspiracy theories. Indeed, in such a country many citizens may feel powerless, as they cannot take an active part in the political life of their country, they also may feel socially threatened, as the risk of losing one's job is tangible and, finally, they are likely to perceive their country's institutions and authorities as untrustworthy, as they see them as corrupt. In other words, in this country, the social and psychological conditions favoring the endorsement of conspiracy theories are present for a larger part of the population than in more democratic and less corrupt countries, where the unemployment rate is also lower.

In conclusion, it should be noted that this research has several limitations. The Conspiracy Index we have computed for the 22 countries of this study is based on an opinion survey that was conducted online, which probably limits its demographic representativeness in countries where the Internet is used by only a minority of the population. It also cannot be totally excluded that this Conspiracy Index is partly biased by cultural variables or geopolitical cleavages, although the controls we have carried out suggest that this is not the case. Finally, the number of countries covered by our study is small. This necessarily affects the robustness of our results, which should be replicated with a larger set of countries.

Despites these limitations, this study is, to our knowledge, the first to identify macro-social factors associated with the international variance of belief in conspiracy theories among a sample of more than twenty Western and non-Western countries. Results of this study, conducted at the international level, corroborate and extend those of existing research at the national level. 


\section{Biographies}

Laurent Cordonier holds a Ph.D in social sciences from the University of Lausanne. He is currently associate researcher at Paris-Diderot University. His work focuses on children's socialization process, social cognition, collective beliefs, and on exploring how some methods and knowledge of cognitive science can be integrated into classical sociological paradigms. In 2018 he published La Nature du social. L'apport ignoré des sciences cognitives (The Nature of the Social. The Overlooked Input of Cognitive Science) at the Presses Universitaires de France.

Florian Cafiero is a research engineer at the Groupe d'étude des méthodes de l'analyse sociologique de la Sorbonne (GEMASS). A specialist in quantitative sociology and computational social science, he is a lecturer in quantitative methods for social science and humanities and in social networks at PSL University. His work has focused on the politicization and fragmentation of social movements around vaccine controversies, but also on conspiracy theories and radicalization.

Gérald Bronner is professor of sociology at Paris-Diderot University and member of the National Academy of Technologies of France (NATF) and the French Academy of Medicine. He works in particular on collective beliefs and cognitive sociology and published in 2013 La Démocratie des crédules (The Democracy of the Gullible) at the Presses Universitaires de France.

\section{Funding}

The authors disclosed receipt of the following financial support for the research, authorship, and/or publication of this article: this study was conducted as part of a project funded by the French Agence Nationale de la Recherche (ANR) entitled 'CONSPIRACY - Responding to the spreading of conspiracy theories' (ANR-17-CE39-0010-01).

\section{References}

Abalakina-Paap M, Stephan WG, Craig T, et al. (1999) Beliefs in conspiracies. Political Psychology 20(3): 637-647.

Barkun M (2003) A Culture of Conspiracy. Apocalyptic Visions in Contemporary America. Berkeley: University of California Press.

Bronner G (2013) La Démocratie des crédules. Paris: Presses Universitaires de France.

Bronner G (2015) Pourquoi les théories du complot se portent-elles si bien ? L'exemple de Charlie Hebdo. Diogène 249-250(1): 9-20.

Brotherton R, Eser S (2015) Bored to fears: Boredom proneness, paranoia, and conspiracy theories. Personality and Individual Differences 80: 1-5.

Brotherton R, French CC (2014) Belief in conspiracy theories and susceptibility to the conjunction fallacy. Applied Cognitive Psychology 28(2): 238-248.

Brotherton R, French CC, Pickering AD (2013) Measuring belief in conspiracy theories: The generic conspiracist beliefs scale. Frontiers in Psychology 4: 1-15.

Bruder M, Haffke P, Neave N, et al. (2013) Measuring individual differences in generic beliefs in conspiracy theories across cultures: Conspiracy mentality questionnaire. Frontiers in Psychology 4: $1-15$.

Coppedge M, Gerring J, Knutsen CH, et al. (2019) V-Dem Codebook v9. Varieties of Democracy ( $\mathrm{V}$ Dem) Project. Available at: https://www.v-dem.net/en/data/archive/previous-referencematerials/reference-materials-v9/ 
Cordonier L (2021) Le succès des théories du complot. Flambée d'irrationalité ou symptôme d'une crise de confiance ? In: Baechler J, Bronner G (eds) L'Irrationnel aujourd'hui. Paris: Hermann, 243262.

DiGrazia J (2017) The social determinants of conspiratorial ideation. Socius: Sociological Research for a Dynamic World 3: 1-9.

Douglas KM, Sutton RM, Callan MJ, et al. (2016) Someone is pulling the strings: Hypersensitive agency detection and belief in conspiracy theories. Thinking and Reasoning 22(1): 57-77.

Drochon H (2018) Who believes in conspiracy theories in Great Britain and Europe? In: Uscinski JE (ed.) Conspiracy Theories and the People Who Believe them. New York: Oxford University Press, 337-346.

Economist Intelligence Unit (2019) Democracy Index 2019. A Year of Democratic Setbacks and Popular Protest. Available at: https://www.eiu.com/topic/democracy-index/

Goertzel T (1994) Belief in conspiracy theories. Political Psychology 15(4): 731-742.

Hofstadter R (1996) The Paranoid Style in American Politics and Other Essays. Cambridge: Harvard University Press.

Lantian A, Muller D, Nurra C, et al. (2016) Measuring belief in conspiracy theories: Validation of a French and English single-item scale. International Review of Social Psychology 29(1): 1-14.

Levenson C (2020) Le complotisme à l'origine de l'antisémitisme noir aux États-Unis. Slate, 27 January. Available at: http://www.slate.fr/story/186443/etats-unis-antisemitisme-vagueviolences-attaques-communaute-juive-afro-americaine-tensions-theorie-complot?

Mancosu M, Vassallo S, Vezzoni C (2017) Believing in conspiracy theories: Evidence from an exploratory analysis of Italian survey data. South European Society and Politics 22(3): 327-344.

Mashuri A, Zaduqisti E, Sukmawati F, et al. (2016) The role of identity subversion in structuring the effects of intergroup threats and negative emotions on belief in anti-West conspiracy theories in Indonesia. Psychology and Developing Societies 28(1): 1-28.

Mazzocchetti J (2012) Sentiments d'injustice et théorie du complot. Représentations d'adolescents migrants et issus des migrations africaines (Maroc et Afrique subsaharienne) dans des quartiers précaires de Bruxelles. Brussels Studies 63. https://doi.org/10.4000/brussels.1119

Shapiro GK, Holding A, Perez S, et al. (2016) Validation of the vaccine conspiracy beliefs scale. Papillomavirus Research 2: 167-172.

Sullivan D, Landau MJ, Rothschild ZK (2010) An existential function of enemyship: Evidence that people attribute influence to personal and political enemies to compensate for threats to control. Journal of Personality and Social Psychology 98(3): 434-449.

Swami V (2012) Social psychological origins of conspiracy theories: The case of the Jewish conspiracy theory in Malaysia. Frontiers in Psychology 3: 1-9.

Swami V, Coles R, Stieger S, et al. (2011) Conspiracist ideation in Britain and Austria: Evidence of a monological belief system and associations between individual psychological differences and realworld and fictitious conspiracy theories. British Journal of Psychology 102(3): 443-463.

Swami V, Voracek M, Stieger S, et al. (2014) Analytic thinking reduces belief in conspiracy theories. Cognition 133(3): 572-585.

Uscinski JE, Parent JM (2014) American Conspiracy Theories. New York: Oxford University Press.

Van Prooijen JW (2017) Why education predicts decreased belief in conspiracy theories. Applied Cognitive Psychology 31(1): 50-58.

Van Prooijen JW, Acker M (2015) The influence of control on belief in conspiracy theories: Conceptual and applied extensions. Applied Cognitive Psychology 29(5): 753-761.

Van Prooijen JW, Krouwel APM, Pollet TV (2015) Political extremism predicts belief in conspiracy theories. Social Psychological and Personality Science 6(5): 570-578.

Wagner-Egger P, Delouvée S, Gauvrit N, et al. (2018) Creationism and conspiracism share a common 
teleological bias. Current Biology 28(16): R867-R868.

World Economic Forum (2017) Executive Opinion Survey. In: The Global Competitiveness Report 2017-2018, 333-340. Available at: http://www3.weforum.org/docs/GCR20172018/05FullReport/TheGlobalCompetitivenessReport2017\%E2\%80\%932018.pdf

Yablokov I (2015) Conspiracy theories as a Russian public diplomacy tool: The case of Russia Today (RT). Politics 35(3-4): 301-315.

YouGov (2018) Conspiracy theories. Available at: https://d25d2506sfb94s.cloudfront.net/cumulus_uploads/document/pk1qbgil4c/YGC\%20Conspir acy\%20Theories\%20\%28all\%20countries\%29.pdf 